Journal Of The Marine Biological Association Of The United

Kingdom

August 2017, Volume 97 Issue 5 Pages 935-942

http://dx.doi.org/10.1017/S0025315417000571

http://archimer.ifremer.fr/doc/00431/54224/

(c) Marine Biological Association of the United Kingdom, 2017

\title{
Loimia ramzega sp nov., a new giant species of Terebellidae (Polychaeta) from French waters (Brittany, English Channel)
}

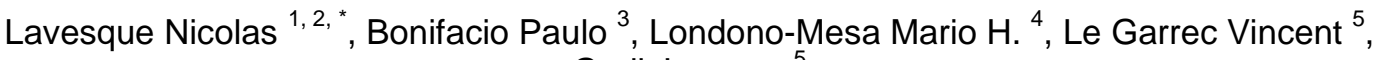 \\ Grall Jacques ${ }^{5}$
}

\footnotetext{
${ }^{1}$ Univ Bordeaux, EPOC, UMR 5805, Stn Marine Arcachon, 2 Rue Prof Jolyet, F-33120 Arcachon, France.

${ }^{2}$ CNRS, EPOC, UMR 5805, Stn Marine Arcachon, 2 Rue Prof Jolyet, F-33120 Arcachon, France.

${ }^{3}$ IFREMER, Inst Carnot, Ctr Bretagne, REM EEP,EDROME,Lab Environm Profond,ZI Pointe du, CS 10070, F-29280 Plouzane, France.

${ }^{4}$ Univ Antioquia, Fac Ciencias Exactas \& Nat, Inst Biol, Grp LimnoBasE \& Biotamar, Calle 70 52-21, Medellin, Antioquia, Colombia.

${ }^{5}$ Univ Brest, CNRS, UMS 3113, OSU IUEM, Rue Dumont Urville, F-29280 Plouzane, France.
}

Corresponding author email address : n.lavesque@epoc.u-bordeaux1.fr

\begin{abstract}
:
A new species of Terebellidae, Loimia ramzega sp. nov., has been identified from North Brittany beaches (English Channel). This new species is characterized by its gigantic size (max $650 \mathrm{~mm}$, live), two pairs of lateral lappets on segments 1 and 3; first pair more ventral, second pair more developed and lateral but oblique, with wavy edge. Nine ventral pads from segment 2 (fused on segments 2 and 3 ), first three pads swollen, next ones subsequently decreasing in size. Three types of notochaetae, asymmetrically bilimbate, symmetrically bilimbate and capillary. Uncini pectinate with 6 teeth (some with 5 teeth) slightly decreasing in size, in one vertical row. Pygidium with about 14 long conical marginal papillae surrounding anus.
\end{abstract}

Keywords : Terebellinae, morphology, molecular, taxonomy, DNA COI 16S, North-east Atlantic, France 


\section{INTRODUCTION}

Terebellids belong to a very species-rich group of sedentary polychaetes, widely distributed in most of marine benthic substrates, from shallow waters to deep-sea environments (Rouse \& Pleijel, 2001). Terebellidae Johnston, 1846 is currently subdivided into 3 subfamilies: Polycirrinae Malmgren, 1867, Terebellinae Johnston, 1846 (frequently referred to as Amphitritinae) and Thelepodinae Hessle, 1917 (as Thelepinae) (Londoño-Mesa \& CarreraParra, 2005). However, Nogueira et al. (2013) carried out a large phylogenetic analysis which resulted in splitting the family Terebellidae into four families: Polycirridae, Terebellidae (= previous Terebellinae), Telothelepodidae, and Thelepodidae (Hutchings et al., in press). Herein, the former proposal will be followed (Read, 2016).

According to Carrerette \& Nogueira (2015), this family includes around 300 species belonging to 50 genera. Among the subfamily Terebellinae, the genus Loimia Malmgren, 1865 currently comprises 28 valid species, of which 7 have been recently described from Brazilian and Australian coasts (Carrerette \& Nogueira, 2015; Nogueira et al., 2015). This genus can be found worldwide, especially occurring in tropical waters (Read \& Bellan, 2011), with only two species known from European waters. Loimia arborea Moore, 1903a was recorded from the Mediterranean Sea (RESOMAR - French marine stations and observatories network - database, http://resomar.cnrs.fr/bases/index.php; Faulwetter, 2010) and from Irish Sea (Guiry \& Guiry, 2011). However, these records are doubtful since this species originated from Japan. According to World Register of Marine Species, validation of these occurrences and species presence beyond Japanese waters is needed (WoRMS, 2008). Loimia medusa (Savigny in Lamarck, 1818) was previously believed to occur from the Mediterranean to Norway but this species was redescribed by Hutchings \& Glasby (1995) who suggested that its distribution may restricted to the Arabian Sea Region. Due to the lack of accurate literature, many European studies have identified their specimen as Loimia sp. (e.g. Mackie et $a l ., 1995$ in the southeastern Irish Sea; RESOMAR database along the French coasts). Since 2011, one of the authors (JG) regularly found specimens of a giant species of Loimia within Northern Brittany beaches that could not be related to any described species. The present paper provides the description of this new species based on morphological characters and supplemented by molecular data. The geographical origin of the species, perhaps not originating from Europe, is discussed. 


\section{MATERIALS AND METHODS}

\section{Sampling and morphological analyses}

The first specimens of this new Loimia species were sampled in 2011 from intertidal sandy beaches of the English Channel (Brittany, France) (Figure 1) after notification of strange large annelids tubes (Figure 2A) by Michel Glémarec (senior French benthic ecologist from Brest University). Specimens examined in this study were collected in 2011, 2012 and 2016 by hand, using a shovel-fork and a technique called "finger tube tracking" allowing the monitoring of the tube position and changes in direction at any moment (Figure 2B). Live specimens were anaesthetized with 7\% magnesium chloride $\left(\mathrm{MgCl}_{2}\right)$ and photographed using a Canon EOS 600D Camera. A small piece of body was removed from several specimens and fixed in $96 \%$ ethanol for molecular studies. The main material was fixed in $4 \%$ formaldehyde seawater solution, then transferred to ethanol $70 \%$ solution for morphological analysis. Preserved specimens were examined under a Nikon SMZ25 stereomicroscope and a Nikon Eclipse E400 microscope, and photographed with a Nikon DS-Ri 2 camera. Total length, length of thorax and width of thorax $\left(10^{\text {th }}\right.$ chaetiger $)$ were measured with the NIS-Elements Analysis software. Drawings were made from pictures using Inkscape software and Wacom Intuos 5 tablet. Holotype and most paratypes were deposited at the Muséum National d'Histoire Naturelle, Paris (MNHN), other paratypes were deposited in the National Museum Wales, Cardiff (NMW-Z) and in Colección Estuarina y Marina, Universidad de Antioquia (CEMUA) in Medellín, Colombia. Additional material was lodged in collections of Arcachon and Brest Marine Stations, in France.

\section{DNA isolation, amplification and sequencing}

Sub-samples for DNA analysis were removed from live specimens, placed in ethanol $96 \%$ and frozen at $-20^{\circ} \mathrm{C}$. Extraction of DNA was done with NucleoSpin Tissue (Macherey-Nagel) kit following protocol supplied by the manufacturers. About $450 \mathrm{bp}$ of $16 \mathrm{~S}$ and $700 \mathrm{bp}$ of COI (cytochrome c oxidase subunit I) genes were amplified using primers Ann16SF and 16SbrH for 16S (Palumbi, 1996; Sjölin et al., 2005), and polyLCO and polyHCO for COI (Carr et al., 2011). The PCR (Polymerase Chain Reaction), with $25 \mu \mathrm{L}$ mixtures contained: $5 \mu \mathrm{L}$ of Green GoTaq ${ }^{\circledR}$ Flexi Buffer (final concentration of $1 \mathrm{X}$ ), $2.5 \mu \mathrm{L}$ of $\mathrm{MgCl} 2$ solution (final concentration of $2.5 \mathrm{mM}$ ), $0.5 \mu \mathrm{L}$ of PCR nucleotide mix (final concentration of $0.2 \mathrm{mM}$ each $\mathrm{dNTP}$ ), $9.875 \mu \mathrm{L}$ of nuclease-free water, $2.5 \mu \mathrm{l}$ of each primer (final concentration of $1 \mu \mathrm{M}$ ), 2 
$103 \mu$ template DNA and 0.125 of GoTaq ${ }^{\circledR}$ G2 Flexi DNA Polymerase (Promega). The 104 temperature profile was as follows: $95^{\circ} \mathrm{C} / 240 \mathrm{~s}-\left(94^{\circ} \mathrm{C} / 30 \mathrm{~s}-52^{\circ} \mathrm{C} / 60 \mathrm{~s}-72^{\circ} \mathrm{C} / 75 \mathrm{~s}\right) * 35$ cycles 105 (for $16 \mathrm{~S}$ ) or $* 40$ cycles (for COI) $-72^{\circ} \mathrm{C} / 480 \mathrm{~s}-4^{\circ} \mathrm{C}$. PCR-products, which produced light 106 bands after electrophoresis on 1\% agarose gel, were sent to the MacroGen Europe Laboratory 107 in Amsterdam (Netherlands) to obtain sequences, using same set of primers as used for the 108 PCR. Overlapping sequence (forward and reverse) fragments were merged into consensus

109

110

111

112 sequences using Geneious Pro 8.1.7 2005-2015 (Biomatters Ltd.) and aligned using the plugins: MAAFT (Katoh et al., 2002) for 16S and MUSCLE (Edgar, 2004) for COI. For COI, the sequences were translated into amino acid alignment and checked for stop codons to avoid pseudogenes. The minimum length coverage was around $450 \mathrm{bp}$ for $16 \mathrm{~S}$ and $610 \mathrm{bp}$ for COI. All sequences obtained in this study have been deposited in GenBank (http://www.ncbi.nlm.nih.gov/genbank/).

\section{RESULTS}

\section{SYSTEMATICS}

Family TEREBELLIDAE Johnston, 1846

Subfamily TEREBELLINAE Johnston, 1846

Genus Loimia Malmgren, 1865

Type species: Terebella medusa Savigny in Lamarck, 1818

GENERIC DIAGNOSIS

Malmgren (1865: 380). Hessle (1917: 170). Hutchings and Glasby (1995: 149-150).

Branchiae on segments 2-4; lateral lappets on segments 1 and 3,1 and 2/3 (in combination of segments 2 and 3) or 1, 3 and 4; ventral shields from segment 2 or 3; nephridial papillae on segments 3-4 and 6-8; 17 pairs of thoracic notopodia from segment 4; chaetae alimbate, unilimbate, symmetrical or asymmetrically bilimbate, smooth tipped; neuropodia from segment 5, uncini avicular or pectinate with a single vertical series of teeth, arranged in single rows on segment $5-10$, in double rows, back to back, up to segment 20 , and in single rows along the abdomen; pygidium sometimes with anal cirri or papillae. 
Loimia ramzega sp. nov.

(Figures 2-5)

135

TYPE MATERIAL

137

Holotype: anterior fragment, 139 segments, $254.2 \mathrm{~mm}$ long; thorax $58.6 \mathrm{~mm}$ long and 15.84 mm wide (MNHN-IA-TYPE 1788); France, English Channel, Brittany, Plouguerneau, Lilia beach $\left(48^{\circ} 37^{\prime} 37.2^{\prime \prime} \mathrm{N}, 4^{\circ} 34^{\prime} 08.5^{\prime \prime} \mathrm{W}\right)$, intertidal, 23 February 2016.

Measured Paratypes: complete specimen, broken, 165 segments, $241.13 \mathrm{~mm}$ long; thorax $65.56 \mathrm{~mm}$ long and $13.23 \mathrm{~mm}$ wide (MNHN-IA-TYPE 1789), anterior fragment, 41 segments, $68.5 \mathrm{~mm}$ long; thorax $63.29 \mathrm{~mm}$ long and $13.11 \mathrm{~mm}$ wide (MNHN-IA-TYPE 1790); France, location and sampling as for holotype. Anterior fragment, 47 segments, 154.37 mm long; thorax $74.64 \mathrm{~mm}$ long and $13.22 \mathrm{~mm}$ wide (MNHN-IA-TYPE 1791), anterior fragment, 46 segments, $130.91 \mathrm{~mm}$ long; thorax $64.52 \mathrm{~mm}$ long and $13.44 \mathrm{~mm}$ wide (MNHNIA-TYPE 1792); France, English Channel, Brittany, Landéda beach, (48³6'37.7" N, 04³6'24.5" W), intertidal, 25 January 2012.

Other Paratypes: 6 anterior fragments, 6 abdominal fragments, 3 posterior fragments (NMW.Z.2017.002.0001); France, English Channel, Brittany, Landéda beach, (48³6'37.7" N, 04³6'24.5" W), intertidal, 27 December 2011; one complete specimen (NMW.Z.2017.002.0002), one anterior fragment (CEMUA-POLY-TERE-0100); France,

152 English Channel, Brittany, Landéda beach, (48³6'37.7" N, 04³6'24.5" W), intertidal, 25 January 2012.

154

ADDITIONAL MATERIAL

Four anterior fragments and 2 posterior fragments (Arcachon Marine Station Collection); 157 France, English Channel, Brittany, Landéda Beach (48³6'37.7" N, 04³6'24.5" W), intertidal, 15825 January 2012. One anterior fragment (Arcachon Marine Station Collection), 2 anterior 159 fragments (Brest Marine Station Collection); France, English Channel, Brittany, 160 Plouguerneau, Lilia Beach (48³7'37.2" N, 4³4'08.5" W), intertidal, 23 February 2016. 
163 Gigantic size ( $\max 650 \mathrm{~mm}$, live), two pairs of lateral lappets on segments 1 and 3; first pair 164 more ventral, second pair more developed and lateral but oblique, with wavy edge. Nine 165 ventral pads from segment 2 (fused on segments 2 and 3), first three pads swollen, next ones 166 167 168 decreasing in size. Uncini pectinate with 6 teeth (some with 5 teeth) slightly decreasing in size, in one vertical row. Pygidium with about 14 long conical marginal papillae surrounding anus.

DESCRIPTION (BASED ON HOLOTYPE AND PARATYPES, MNHN)

Tube long and only $17 \mathrm{~mm}$ in width, made of shells fragments and small gravels, emerging end with fragments of macroalgae attached, inner surface with strong smooth membrane allowing tube to maintain a hard consistency (Figures 2A, C). In life, body colour pinkish to light green (Figures 2C, D); buccal tentacles translucent; upper lip light pink; first pair of lateral lappets white with blood red margins (Figure 2C); second pair blood red; branchiae blood red; first ventral pad whitish, second one whitish anteriorly and blood red posteriorly, ventral pads from segment 5 to 11 (S5 to S11) blood red and with tiny whitish lateral bands, shields from S12 to end of thorax dark red (Figure 2C). Dorsal posterior part of abdomen with dark spots. Formalin fixed body with brownish lappets, ventral shields from S4 to S11 light brown, others dark brown, dorsal-posterior margin of thoracic segment light orange. In alcohol, body whitish.

Tentacles abundant and long, reaching end of thorax when projecting backward on live specimens (Figure 3), without ridges, with a deep groove. Eyespots absent from very developed tentacular membrane. Upper lip rounded, with free edge, projecting forward. Lower lip small, completely covered ventrally by membrane connecting lappets of segment 1 . Lateral lappets discontinuous, 2 pairs on S1 and S3. First pair large, oval, projecting forwards, merged ventrally (originating ventrally), covering upper lip (Figures 3, 4A). Second pair of lateral lappets the largest, laterally concealing S2, originating ventro-laterally and connected to first ventral shields, anterior margin wrinkled or wavy, dorsolaterally ear-shaped, covering the base of the first and second pairs of branchiae (Figure 3).

191 Three pairs of arborescent branchiae, long, starting from S2, first pair longest, projecting forward, third pair smallest. Branchiae with thick stalks, and many dendritic branches arranged in five levels (Figure 3). Nephridial papillae, tube-like, from S3-4 and S6-8. Whitish glandular patches, gradually decreasing in size, surrounding the first eleven notopodia (Figure 
4B). Sixteen ventral shields from S2, fused on S2-S3 (Figures 2C, 4C), not subdivided, progressively narrower and more indented posteriorly by neuropodia from S12 to S17. Ventral shields more evident in live specimens, appearing as blood red pigmentation (Figure 2C). Abdomen ventrally smooth.

Notopodia from S4, extending through S20. Notopodial lobes well developed (Figure 4B), first notopodia button-like. Notochaetae of three types within a fascicle: long serrated, asymetrically bilimbate; long bilimbate, serrated, with narrow limbs; and slightly shorter alimbate capillaries few in number, around 1:10 relative to long chaetae (Figure 5A). Thoracic neuropodia as a ventrolateral belts of uncini, decreasing in width toward the posterior thoracic region. Abdominal neuropodia long, projected posteriorly, with narrow belt of uncini along posterior margins. Thoracic $(\mathrm{n}=280$ to 350$)$ and abdominal $(\mathrm{n}=90$ to 110$)$ uncini pectinate, arranged in double rows from segment 11, similar in size and shape, with 6 teeth in single vertical row, some uncini with 5 teeth (Figures 5B, C). Uncini long with curved occipitium, posterior process absent, basis concave, anterior process absent, anterior filament long, projected downwards, long and narrow subrostrum, subrostral process absent. Pygidium with terminal rounded anus, surrounded by 14 long, conical papillae (Figure 5D).

\section{VARIATION}

One paratype (MNHN-IA-TYPE 1790) with the first pair of lateral lappets showing a deep anterodorsal notch. One posterior part of additional material with only 12 pygidial papillae, but probably two lost. Remaining characters strictly similar to holotype.

\section{DNA}

COI and 16S genes were successfully sequenced and published at NCBI GenBank for: holotype MNHN-IA-TYPE 1788 accession number 16S: KY555058 and COI: KY555061; paratypes MNHN-IA-TYPE 1789 accession number 16S: KY555059 and COI: KY555062 and MNHN-IA-TYPE 1790 accession number 16S: KY555060 and COI: KY555063.

\section{ETYMOLOGY}

The species name ramzega refers to the gigantic size of this species. In Breton "ramzeg" means titanic, giant. 
DISTRIBUTION

228 Only known from France, English Channel, North Brittany (along $60 \mathrm{~km}$ ) and from Molène 229 island; on sandy beaches, intertidal (Figure 1)

\section{DISCUSSION}

232

According to Holthe (1986), the genus Loimia had 16 valid and described species, one subspecies and 4 synonymized species. However, Read \& Bellan (2011) stating recent newly described species, reported 28 valid species and one nomen dubium. This genus shows a tropical distribution, with only few subtropical species, and no arctic species. Loimia medusa, the type species described from the Red Sea, has long been erroneously identified in many distant localities, hiding possible new species identifications (Hutchings \& Glasby, 1995). Thus, true cosmopolitan species are now a topical subject for debate by marine taxonomists (Hutchings, 2016). Recently, new species of polychaetes have been identified from supposed well studied localities (Londoño-Mesa, 2009; Carrerete \& Nogueira, 2015; Nogueira et al., 2015). Concerning European waters, no species belonging to the genus Loimia has been officially described, although some specimens originating from the area may have been erroneously deposited in museums under the name L. medusa. Thus, the present description of L. ramzega sp. nov. may offer a local solution for those misidentified species but given the presence of Loimia sp. in the south-eastern Irish Sea (Mackie et al., 1995), there are probably more undescribed Loimia species in Europe (especially small species) and all specimens should be observed carefully. Indeed, a similar exercise has been done by Londoño-Mesa \& Carrera-Parra (2005) with specimens initially identified as L. medusa from the Caribbean. These authors found that L. medusa does not occur in the western tropical Atlantic, and that the material identified as L. medusa from the region already belonged to three species; one incorrectly hidden by synonymy, Loimia minuta Treadwell, 1929, and one new for science, Loimia salazari Londoño-Mesa \& Carrera-Parra, 2005.

We report L. ramzega sp. nov. for the first time from one of the best known marine ecosystems of the world: The western English Channel. We believe that a species of such size and from an easily accessible habitat could not have been overlooked through 150 years of marine biological study in the area. Indeed, Roscoff and Concarneau Biological stations both founded during the XIXth century, and later the Biological Oceanography laboratory of the 
University of Western Brittany since the 1960s, have lead hundreds of benthic surveys in the area. It is thus very unlikely that the species would not have been noticed before 2011. The main hypothesis for lack of record previous to the 2010s is that L. ramzega sp. nov. could be a non-European indigenous species recently introduced to Brittany. The fact that it has been first identified within two areas with extensive oyster farming of the Pacific Oyster Crassostrea gigas (Thunberg, 1793) (some spat and juveniles being directly imported from marine areas outside France) would support such hypothesis. The question of its area of origin then arises. Another way could be an immigration from southern Europe or Africa. Warming seas with climate change could have brought the species further north. This hypothesis seems unlikely as "tropicalization" of the English Channel is not yet documented, especially in the area (Treguer et al., 2014), at the opposite of Bay of Biscay (Arias \& Crocetta, 2016). Indeed, thermal and haline structures in the Iroise Sea hinder dispersal between the Bay of Biscay and English Channel and numerous benthic fauna species find their limit of distribution in Brittany (Le Garrec et al., 2016, Gallon et al., in revision). However, because it is so difficult to catch, we cannot exclude the fact that the species may be native from Europe, and when (if) sampled, would have been misidentified under the name L. medusa.

Loimia ramzega sp. nov. is easily identifiable by its very large size, the pigmentation on the ventral shields, and the development of its lateral lappets. Before this record, the largest species within the genus was L. salazari from the Mexican Caribbean, at $221 \mathrm{~mm}$ length, but it differs from L. ramzega by having avicular instead of pectinate uncini.

We do not believe that the very large size of L. ramzega represents a reliable example of gigantism. Indeed gigantism is rather known from polar or abyssal environments (Moran \& Woods, 2002) and not from intertidal temperate waters. Gigantism that would result from a consequence of a pollution is also dismissed. Indeed, sampling sites are not particularly affected by anthropogenic perturbations. Moreover, no other benthic invertebrate species from these highly diversified benthic communities are oversized in comparison with other sites or adjacent waters.

Species belonging to Loimia having pectinate uncini, and from geographically close regions are scarce. Loimia viridis Moore, 1903b, from Massachussets (United states), has similar shape on first ventral shields, but it differs from L. ramzega sp. nov, by having pectinate uncini with 7-8 teeth, only one type of notochaeta, being symmetrically bilimbate, and with the second pair of lateral lappets transverse to the body axis. Other Loimia species with pectinate uncini differ by combinations of morphological characters (disposition and number of lateral lappets and number of uncinal teeth) as well as by their geographical distribution. 
292 For example, L. arborea (from Japan) has lateral lappets on segments 1 and 2/3, and thoracic 293 uncini with 5 (rarely 6) teeth, and abdominal ones with 6 (rarely 7) teeth. Loimia batilla 294 Hutchings \& Glasby, 1988 (from Queensland, Australia) has lateral lappets on segments 1 and $2952 / 3$, and thoracic uncini with 6 teeth, and abdominal ones with 7 teeth. Loimia bermudensis 296 Verrill, 1900 (from Bermuda) has lateral lappets on segments 1 and 3, and uncini with 5 teeth 297 (rarely 6 very reduced). Loimia decora Pillai, 1961 (from Sri Lanka) has lateral lappets on 298 segments 1 and 2/3, and uncini having 5 teeth. Loimia grubei Holthe, 1986 (from Philippines) 299 has lateral lappets on segments 1 and 2/3, and thoracic uncini with 5 teeth and abdominal 300 uncini with 6-7 teeth. Loimia triloba Hutchings \& Glasby, 1988 (from Queensland) has three 301 pairs of lateral lappets on segments 1, 3 and 4, and uncini with 5 (rarely 6) teeth. Finally, 302 Loimia verrucosa Caullery, 1944 (from Indonesia) has lateral lappets on segments 1 and 3, 303 and uncini with 7 teeth. Thus, none of the species having pectinate uncini have been described 304 from Europe, and L. ramzega sp. nov. is the first such species being described from the 305 region.

306 Finally, a revision of the genus is ongoing, examining the phylogenetic relationship of the 307 species within the genus based on morphology.

\section{ACKNOWLEDGMENTS}

310 The authors would like to thank Michel Glémarec who observed tubes of this species for the 311 first time and Jerôme Jourde, Sylvain Elies and Nolwenn Quillien for helping to catch the first 312 specimens. We are very gratefully to Andy Mackie and Orlemir Carrerette for their advices 313 when we tried to identify this species. Many thanks to Lenaick Menot and Emmanuelle 314 Omnes from Ifremer-Brest for their support with molecular analysis and Patrice Gonzalez 315 from Arcachon Marine Station for his help with submission of sequences in Genebank. 316 Finally, we also thank Andy Mackie and Pat Hutchings, whose comments have greatly 317 contributed to improve the manuscript. 


\section{REFERENCES}

Arias A. and Crocetta F. (2016) Umbraculum umbraculum (Gastropoda: Heterobranchia) spreading northwards: additional evidence to the "tropicalization" of the Bay of Biscay. Cahiers de Biologie Marine 57: 285-286.

Caullery M. (1944) Polychètes Sédentaires de l'Expédition du Siboga: Ariciidae, Spionidae, Chaetopteridae, Chlorhaemidae, Opheliidae, Oweniidae, Sabellariidae, Sternaspidae, Amphictenidae, Ampharetidae, Terebellidae. Siboga-Expeditie Uitkomsten op Zoologisch, Bonatisch, Oceanographisch en Geologisch gebied verzameld in Nederlandsch Oost-Indië 1899-1900 XXIV 2(bis), 1-204.

Carr C.M., Hardy S.M., Brown T.M., Macdonald T. and Hebert P.D.N. (2011) A trioceanic perspective: DNA barcoding reveals geographic structure and cryptic diversity in Canadian polychaetes. PLoS ONE 6 (7): e22232.

Carrerette O. and Nogueira J.M.M. (2015) The genus Loimia Malmgren, 1866 (Annelida: Terebellidae) off the Brazilian coast, with description of three new species and notes on some morphological characters of the genus. Zootaxa 3999 (1), 1-31.

Edgar R.C. (2004) MUSCLE: Multiple sequence alignment with high accuracy and high throughput. Nucleic Acids Research 32 (5), 1792-1797.

Faulwetter S. (2010). Check-list of marine Polychaeta from Greece. Aristotle University of Thessaloniki. Assembled in the framework of the EU FP7 PESI project.

Gallon R.K., Lavesque N., Grall J., Labrune C., Grémare A., Bachelet G., Blanchet H., Bouchet V., Dauvin J.C., Desroy N., Gentil F., Guérin L., Houbin C., Jourde J., Laurand S., Le Duff M., Le Garrec V., de Montaudouin X., Orvain F., Sauriau P.G., Thiébaut E. and Gauthier $\mathbf{O}$. (in revision). Regional and latitudinal patterns of macrobenthic invertebrates along the French coast: Results from the RESOMAR database. Journal of Sea Research.

Guiry M.D. and Guiry G.M. (2011). Species.ie version 1.0. World-wide electronic publication, National University of Ireland, Galway.

Hessle C. (1917) Zur Kenntnis der Terebellomorphen Polychaeten. Zoologiska Bidrag från Uppsala 5, 39-258. 
Holthe T. (1986) Evolution, systematics, and distribution of the Polychaeta Terebellomorpha, with a catalogue of the taxa and a bibliography. Gunneria 55, 1-236.

Hutchings P. A. (2016). Cosmopolitan species, fact or fiction? $12^{\text {th }}$ International Polychaete Conference, National Museum Wales, Cardiff 1- 5 August 2016. Accessed through: Museum of Wales at https://museum.wales/Presentations/

Hutchings P. A. and Glasby C.J. (1988) The Amphitritinae (Polychaeta: Terebellidae) from Australia. Records of the Australian Museum 40, 1-60.

Hutchings P.A. and Glasby C.J. (1995) Description of the widely reported terebellid polychaetes Loimia medusa (Savigny) and Amphitrite rubra (Risso). Mitteilungen aus dem Hamburgischen Zoologischen Museum und Institut 92, 149-154.

Hutchings P., Nogueira J.M.N. and Carette O. (in press). Terebellidae Johnston, 1846. In Schmidt-Rhaesa A.H., Beutel R.G., Glaubrecht M., Kristensen N.P., Prendini L., Purschke G., Richter S., Westheide W. and Leschen R. (eds) (in press). Handbook of Zoology. A Natural History of the Phyla of the Animal Kingdom.

Johnston G. (1846) An index to the British Annelides. Annals and Magazine of Natural History 1(16), 433-462.

Katoh K., Misawa K., Kuma K. and Miyata T. (2002) MAFFT: A novel method for rapid multiple sequence alignment based on fast Fourier transform. Nucleic Acids Research 30 (14), 3059-3066.

Le Garrec V., Grall J., Chevalier C., Guyonnet B., Jourde J., Lavesque N., Bonifácio P. and Blake J.A. (2016) Chaetozone corona (Polychaeta, Cirratulidae) in the Bay of Biscay: a new alien species for the North-east Atlantic waters? Journal of Marine Biological Association of the United Kingdom 97, 433-435.

Londoño-Mesa M.H. (2009) Terebellidae (Polychaeta: Terebellida) from the Grand Caribbean Region. Zootaxa 2320, 1-93.

Londoño-Mesa M.H. and Carrera-Parra L.F. (2005) Terebellidae (Polychaeta) from the Mexican Caribbean with description of four new species. Zootaxa 1057, 1-44.

Mackie A.S.Y., Oliver P.G. and Rees E.I.S. (1995) Benthic biodiversity in the southern Irish Sea. Studies in Marine Biodiversity and Systematics from the National Museum of Wales. BIOMÔR Reports 1, 1-263. 
Malmgren A.J. (1865) Nordiska Hafs-Annulater. Stockholm: Norstedt \& Söner.

Malmgren A.J. (1867) Annulata Polychaeta Spetsbergice, Grœnlandice, Islandice et Scandinavioe. Hactenus Cognita. Helsingforslae: Ex Officina Frenckelliana.

Moran A.L. and Woods H.A. (2012) Why might they be giants? Towards an understanding of polar gigantism. Journal of Experimental Biology 215, 1995-2002.

Moore J.P. (1903a). Polychaeta from the coastal slope of Japan and from Kamchatka and Bering Sea. Proceedings of the Academy of Natural Sciences of Philadelphia 55, 401-490.

Moore J.P. (1903b). Descriptions of two new species of Polychaeta from Wood's Hole, Massachusetts. Proceedings of the Academy of Natural Sciences of Philadelphia 55, 720-726.

Nogueira J.M.M., Fitzhugh K. and Hutchings P. (2013) The continuing challenge of phylogenetic relationships in Terebelliformia (Annelida: Polychaeta). Invertebrate Systematics 27, 186-238.

Nogueira J.M.M., Hutchings P. and Carrerette O. (2015) Terebellidae (Annelida, Terebelliformia) from Lizard Island, Great Barrier Reef, Australia. Zootaxa 4019, 484-576.

Palumbi S.R. (1996) Nucleic acid II: The polymerase chain reaction. In Hillis D.M., Moritz G. and Mable B.K. (eds) Molecular systematics. Sunderland (MA): Sinauer Associates, pp. 205-247.

Pillai T.G. (1961) Annelida Polychaeta of Tambalagam Lake, Ceylon. Ceylon Journal of Science (Biological Sciences) 4(1), 1-40.

Read G. (2016) Terebellidae Johnston, 1846. In Read G. and Fauchald K. (eds) (2016). World Polychaeta database. Accessed through: World Register of Marine Species at http://www.marinespecies.org/aphia.php?p=taxdetails\&id=982 on 2017-01-26

Read G. and Bellan G. (2011) Loimia Malmgren, 1865. In Read G. and Fauchald K. (eds) (2016). World Polychaeta database. Accessed through: World Register of Marine Species at http://www.marinespecies.org/aphia.php?p=taxdetails\&id=129700 on 2016-09-06.

Rouse G.W. and Pleijel F. (2001) Polychaetes. Oxford: Oxford University Press.

Savigny J.S. (1818) Les Annélides In Lamarck J.B. Histoire naturelle des animaux sans vertèbres, vol. 5. Paris : Déterville \& Verdière. 
406 Sjölin E., Erséus C. and Källersjö M. (2005) Phylogeny of Tubificidae (Annelida, 407 Clitellata) based on mitochondrial and nuclear sequence data. Molecular Phylogenetics and 408 Evolution 35(2), 431-441.

409 Treadwell A.L. (1929) New species of polychaetous annelids in the collections of the 410 American Museum of Natural History from Porto Rico, Florida, Lower California and British 411 Somaliland. American Museum Novitates, 392: 1-13.

412 Tréguer P., Goberville E., Barrier N., L'Helguen S., Morin P., Bozec Y., Rimmelin413 Maurya P., Czamanski M., Grossteffan E., Cariou T., Répécaud M. and Quéméner L. 414 (2014) Large and local-scale influences on physical and chemical characteristics of coastal 415 waters of Western Europe during winter. Journal of Marine Systems 139, 79-90.

416 Verrill A.E. (1900) Additions to the Turbellaria, Nemertina, and Annelida of the Bermudas, 417 with revisions of some New England genera and species. Transactions of the Connecticut 418 Academy of Arts and Sciences 10(2), 595-671.

419 WoRMS (2008) Loimia arborea Moore, 1903. In Read G. and Fauchald K. (eds) (2016). 420 World Polychaeta database. Accessed through: World Register of Marine Species at 421 http://www.marinespecies.org/aphia.php? $\mathrm{p}=$ taxdetails\&id=328859 on 2017-02-08. 


\section{$422 \quad$ Figure legends}

423 Fig. 1. Sampling sites of Loimia ramzega sp. nov. on the Brittany coasts (English Channel, 424 Western France). Dots: presence; star: locality type.

425 Fig. 2. Loimia ramzega sp. nov. A. Tube opening; B. Trench required to collect a single 426 specimen; C. Live specimen in its tube, antero-ventral view; D. Entire live specimen. Scale 427 bars: A, $2 \mathrm{~cm}$; B, $50 \mathrm{~cm}$; D, $10 \mathrm{~cm}$.

428 Fig. 3. Loimia ramzega sp. nov. anterior part, lateral view (holotype MNHN-IA-TYPE 1788). 429 Scale bar: $1 \mathrm{~cm}$.

Fig. 4. Loimia ramzega sp. nov. A. Anterior part, lateral view (holotype MNHN-IA-TYPE 431 1788); B. Anterior part, dorsal view (paratype MNHN-IA-TYPE 1792); C. Anterior part, 432 ventral view (holotype MNHN-IA-TYPE 1788). Numbers refer to segments; LL1 = first 433 lateral lappet; LL2 = second lateral lappet; $\mathrm{p}=$ peristomium; ul = upper lip; br1, br2, br3 refer 434 to the three pairs of branchiae. Scale bars: $5 \mathrm{~mm}$.

435 Fig. 5. Loimia ramzega sp. nov. A. Notochaetae from chaetiger 11 (paratype MNHN-IA436 TYPE 1790); B. Thoracic uncini from segment 12, lateral views (paratype MNHN-IA-TYPE 437 1791); C. Abdominal uncini from segment 25, lateral views (paratype MNHN-IA-TYPE 438 1791); D. Pygidium lateral view (paratype MNHN-IA-TYPE 1789). Scale bars: A 0.1mm; B, $439 \mathrm{C} 25 \mu \mathrm{m} ; \mathrm{D} 0.5 \mathrm{~mm}$. 


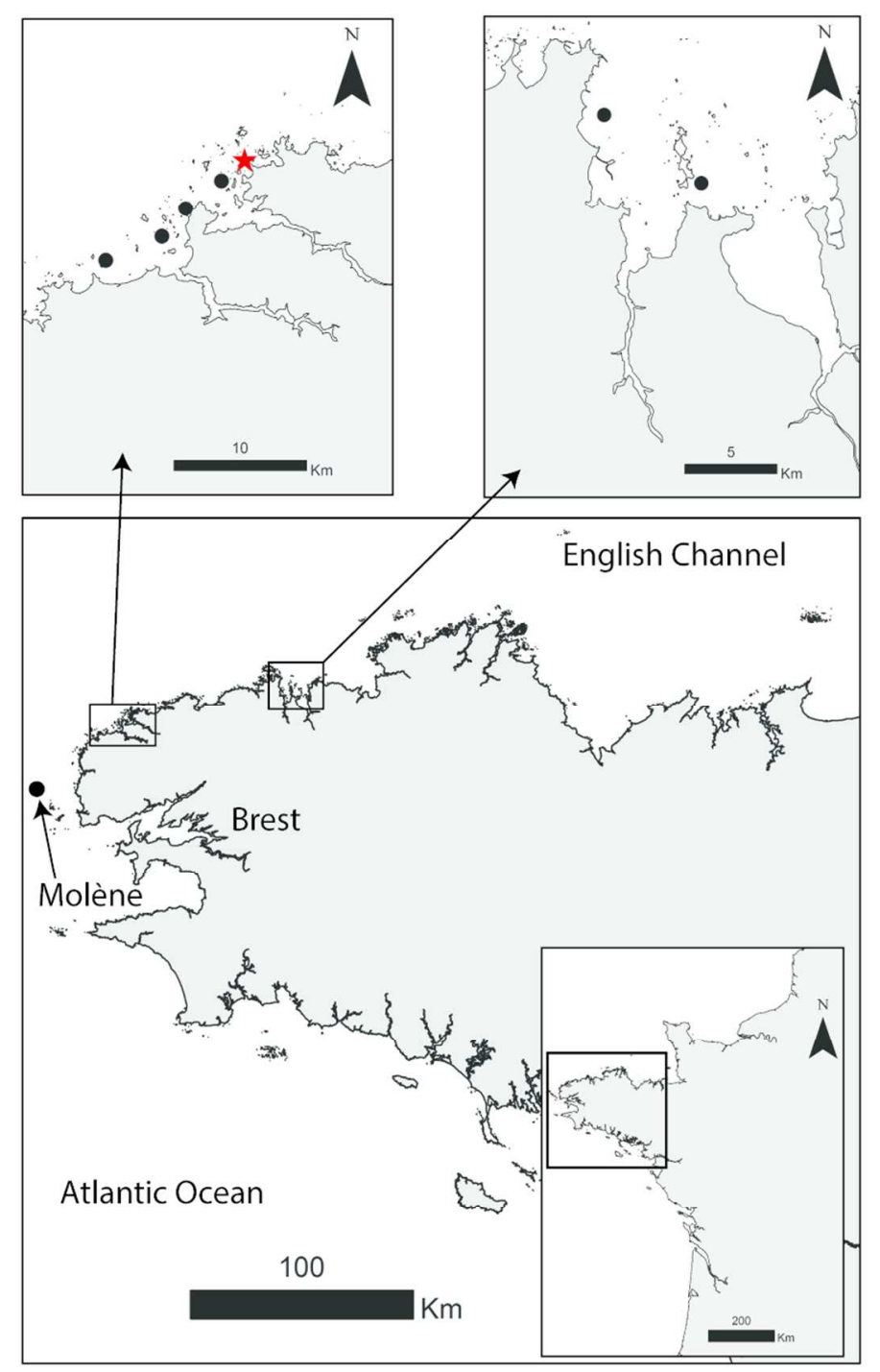

Figure 1

$82 \times 126 \mathrm{~mm}(300 \times 300 \mathrm{DPI})$ 


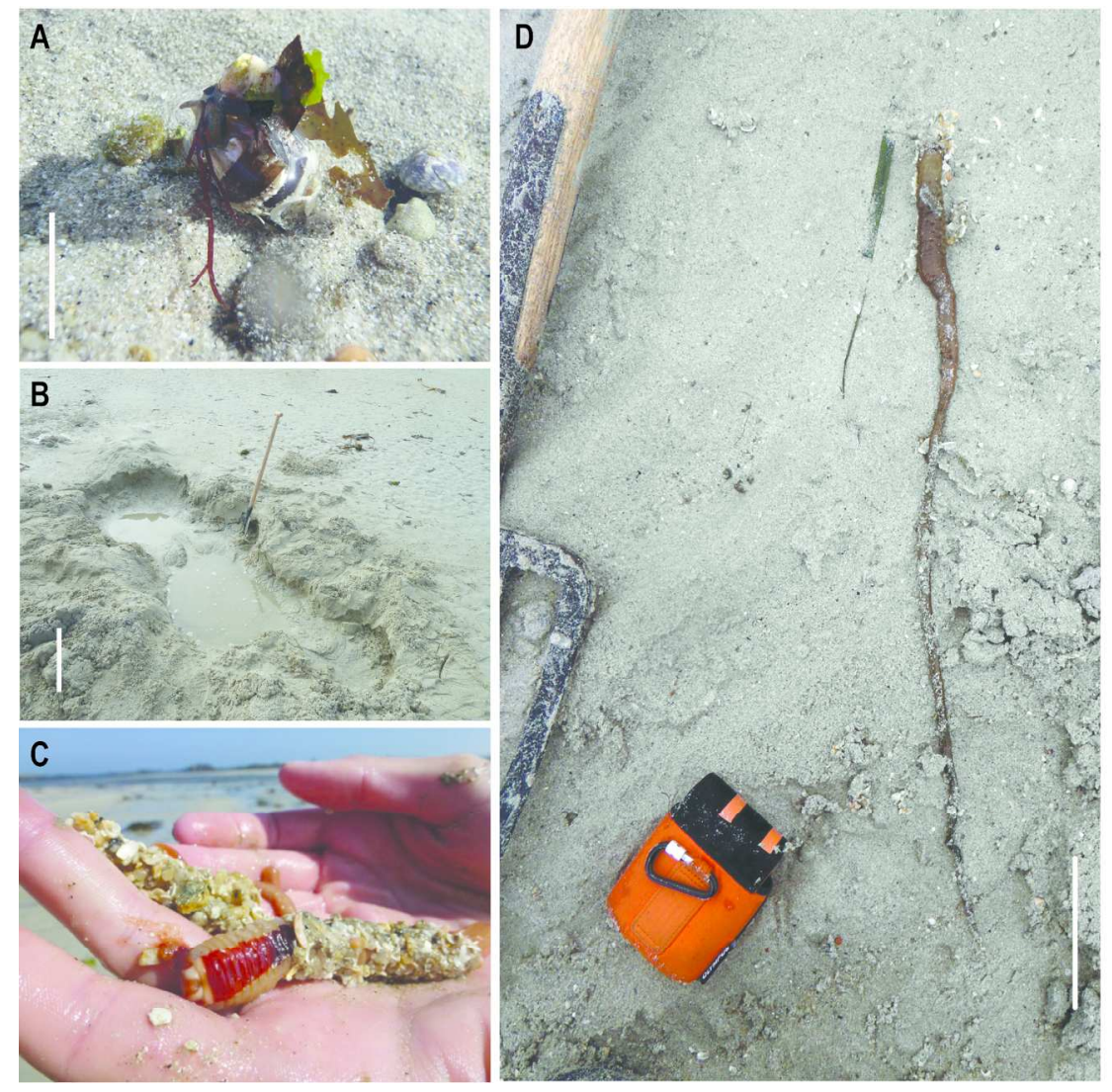

Figure 2

$185 \times 155 \mathrm{~mm}(300 \times 300 \mathrm{DPI})$ 


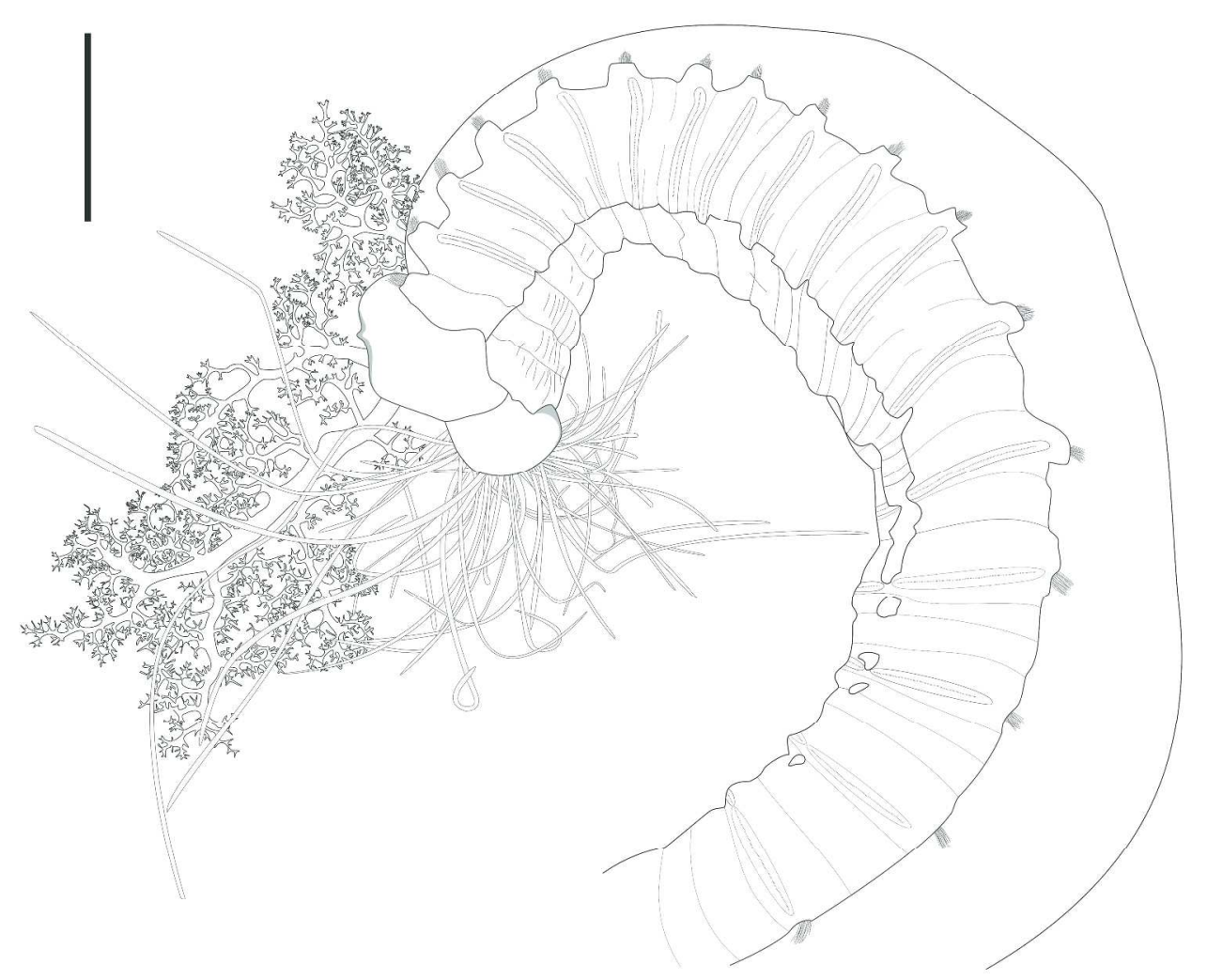

Figure 3

$339 \times 278 \mathrm{~mm}(300 \times 300 \mathrm{DPI})$ 


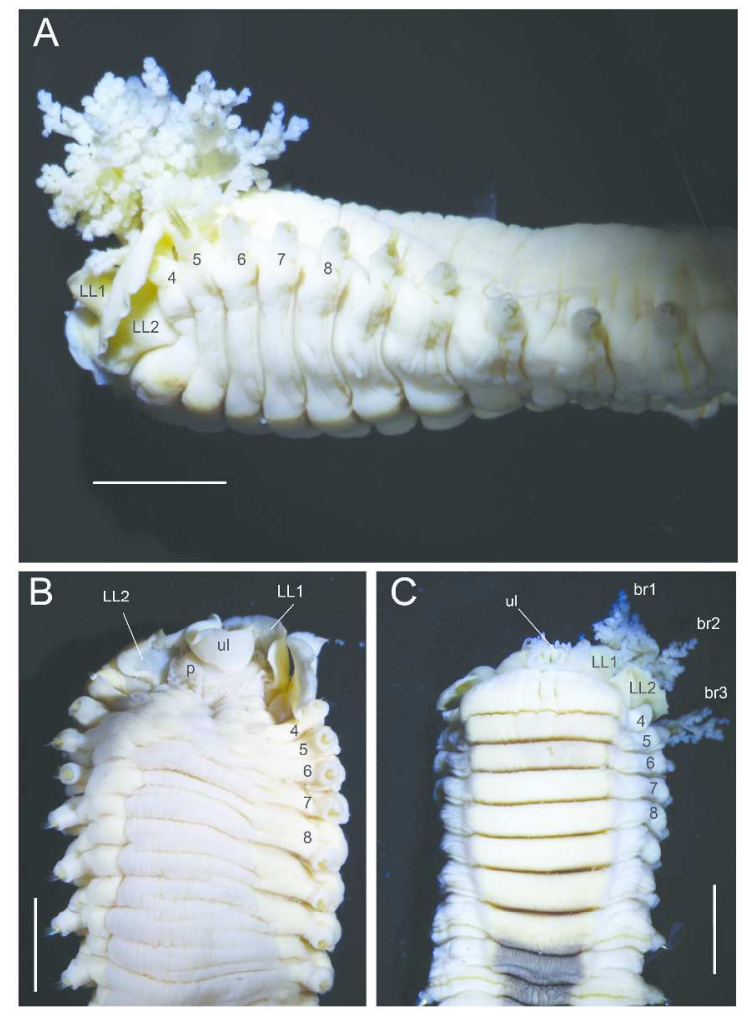

Figure 4

$401 \times 593 \mathrm{~mm}(300 \times 300$ DPI $)$ 

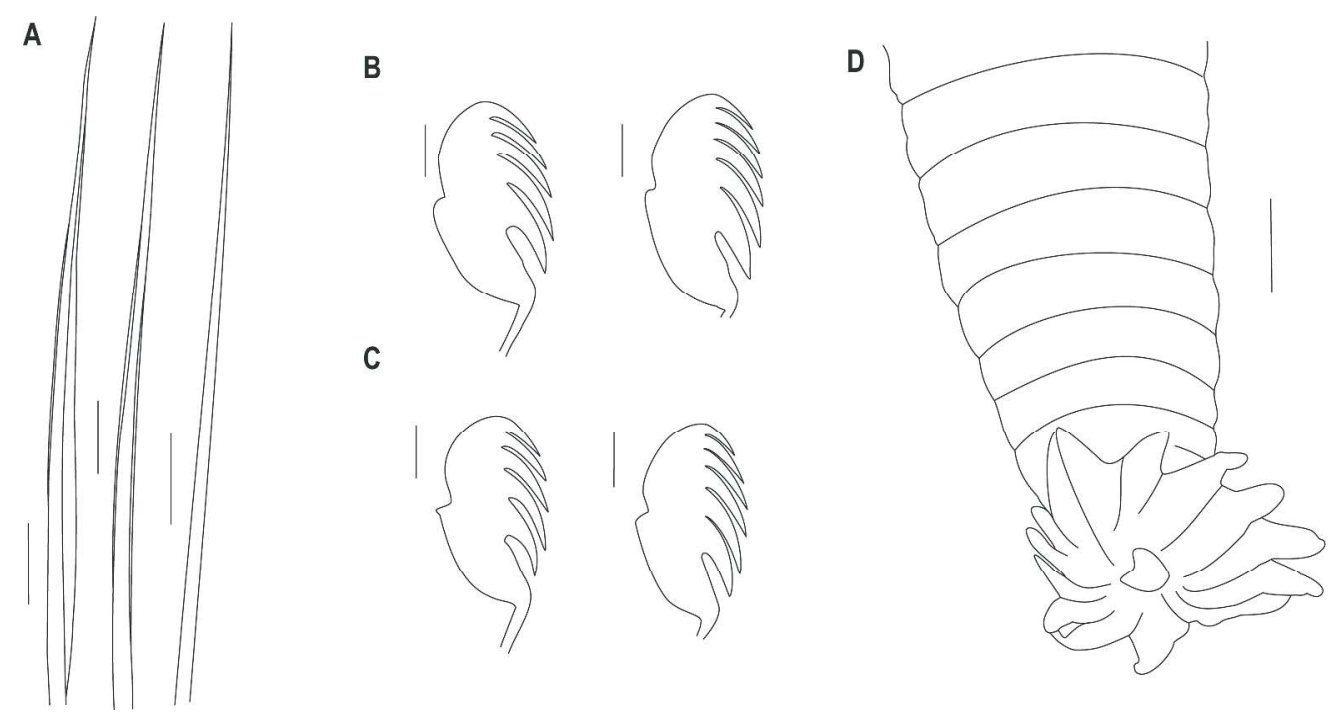

Figure 5

$389 \times 208 \mathrm{~mm}(300 \times 300$ DPI $)$ 